\title{
Socio-Economic and Political Impact of Pandemics in the African Continent and Regional Mechanisms to Mitigate it
}

\author{
Sultan Khan
}

University of KwaZulu-Natal, South Africa

\begin{abstract}
Throughout the history of African societies, pandemics have claimed, in some instances more lives than warfare. Africa is susceptible to many pandemics. Given the state of underdevelopment amongst African nation-states characterised by low levels of education, poor health care facilities, lack of basic infrastructure, poverty, low levels of income, lack of skilled health care workers, and many more factors, it is not sufficiently equipped to handle pandemics that are life-threatening. Hence, it is prone to outbreaks of infectious diseases. Pandemics cause the socio-economic crisis, which in turn affects political stability. In the history of Africa, the Ebola disease, HIVIAids, Cholera are some of the major diseases that have ravished nation-states in contemporary times. Now, just like other parts of the world, it has to deal with the Covid-19 pandemic that has far-reaching consequences. This article seeks to interrogate the nature and causes of major pandemics in the globe and the African continent and the steps taken to ameliorate these. It further examines the impact of pandemics on the socio-economic and political spheres of life in the continent.
\end{abstract}

Keywords: Pandemic, Spanish Flu, Cholera, Covid-19, Ebola, HIV/Aids, Black Death.

\section{INTRODUCTION}

Pandemics has long been a challenge for nationstates often changing the course of history. It has ravaged humanity and at times signals an end to entire civilizations. The socio-economic welfare of nationstates becomes perilous during and after pandemics. In managing pandemics, there is a north-south divide in the globe in the way in which it is responded to minimise its devastating effects on various aspects of societal life. Social, economic, and political stability during and after pandemics is contingent on the capacity of nation-states to contain it and have mechanisms in place to cushion its disastrous effects at the macro, meso, and micro level.

Central to the management of pandemics the availability of resources is of necessity. In developed countries, although not immune to pandemics, more resources are available as compared to their lessdeveloped counterparts. In as far as, Africa as a continent is concerned, given its political history and underdevelopment places it at a disadvantageous position to cope with, and its consequences. The history of pandemics in Africa, some peculiar to the continent and its nation-states, has had devastating consequences on the lives of citizens, loss in economic productivity, breakdown in its societal structures, and its effective functioning. It is in this context that the paper provides an overview of major pandemics in the globe and the African continent, the impact of

*Address correspondence to this author at the University of KwaZulu-Natal, School of Social Sciences, Howard College Campus, Durban, South Africa; Tel: +27 (0)31 2607240; E-mail: Khans@ukzn.ac.za pandemics, and international, continental, and regional responses to pandemics.

\section{OVERVIEW OF PANDEMICS IN THE GLOBE}

Throughout human civilisation, pandemics plagued nation-states across the globe. Jarus (2020) provides a synopsis of the twenty worst epidemics and pandemics in human history. Through archaeological and anthropological evidence he observes that the first prehistoric pandemic was some 5000 years ago in a village in China. In $430 \mathrm{BC}$ the plague of Athens claimed 100000 deaths whilst the Antonine Plague (A.D. 165-180) during the time of the Roman Empire claimed 5 million lives. The Plague of Cyprian (A.D. 250-271) in Tunisia and the Plague of Justinian (A.D. 541-542) in the Byzantine Empire (now Istanbul) ravaged at least ten percent of the global population.

The Black Death (1346-1353) is known to be one of the most catastrophic pandemics that claimed the lives of 50 million people (Benedictow, 2005). The bubonic plague is found among rodents in great density and infects human beings. In the fourteenth century, seaport trade in Europe increased voluminously in the region for the transit of trade goods. However, in this period, cities emerged around ports, which were densely populated. With the emergence of trading networks on the coasts to mountain villages, contagious diseases reached most remote and isolated settlements in the region. The map below illustrates the spread of the virus around port cities in Europe and other neighbouring countries.

Spanish Influenza (1918-1919) as it is known killed more than 50 million people worldwide over two years. 


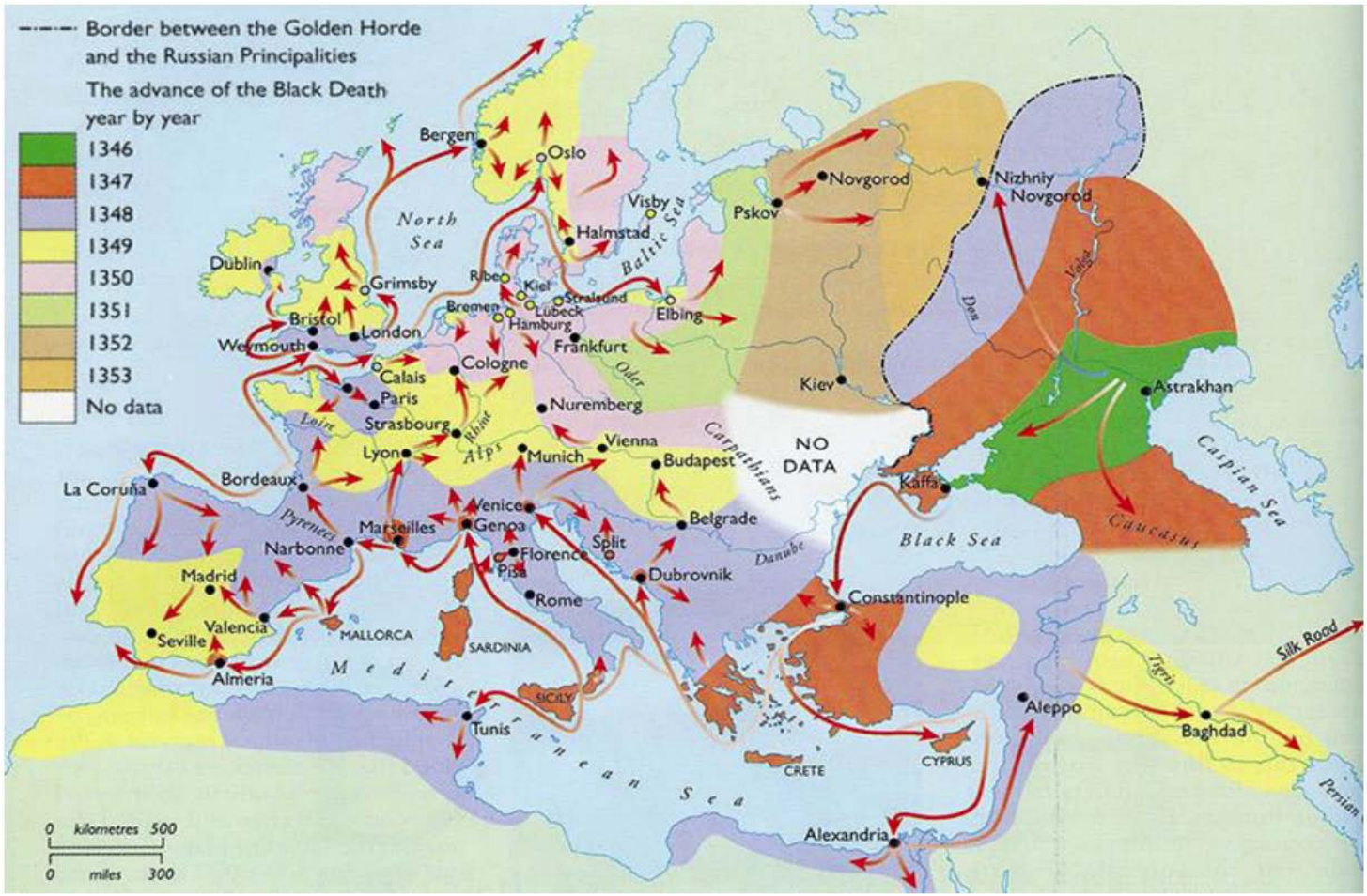

Source: Benedictow, 2005.

The origin of the pandemic is unknown but some suggest that it originated in Kansas, USA and the name Spanish Flu emerged as an inaccuracy as Spain was the first country to report publicly the health crisis during World War I. The pandemic is traceable to soldiers and sailors. Given that the outbreak of the pandemic occurred in a war context, nation-states were ill-equipped to handle this fatal health crisis. There was a lack of physicians and nurses and a strain on medical resources as these were deployed to military hospitals. Doctors and nurses were a scarcity, as many died due to exposure to the pandemic (Ott, et al., 2007). Additionally, the medical fraternity in the world at this time was not able to develop at short notice a vaccine to manage the pandemic. Migration from urban centers to rural areas transmitted through transportation networks along rivers, roads, and railway systems led to the spread of the virus (Africa Center for Strategic Studies, 2020). There was a dearth of knowledge on producing a vaccine during this pandemic. It was only in the 1940s that a vaccine was developed. Even though this vaccine became available, new strains emerged making the earlier ones impotent (Barberis, 2016).

Post World War II, the United Nations Assembly saw the need for a global health organisation in light of pandemics affecting nation-states and the world at large. On 7 April 1948, the World Health Organisation's
(WHO) Constitution came into effect- a date that is celebrated every year as World Health Day. The WHO coordinates, tracks, and provides professional support to nation-states and the globe that are afflicted with infectious diseases. It brings awareness when needed; share expertise and formulate the kind of response needed to protect populations from the consequences of epidemics, whatever and wherever might be their origin. Additionally, the goal of the WHO is to reduce mortality and morbidity levels due to communicable diseases spreading in nation-states affected by political conflict, natural disasters, and food insecurity.

During the 19th century, cholera spread across the world from its origin in the Ganges delta in India. Thereafter, six subsequent pandemics killed millions of people across all continents. The current (seventh) pandemic started in South Asia in 1961 and reached Africa in 1971 and the Americas in 1991. Cholera is now endemic in many countries. It remains a major public health problem and affects primarily developing world populations with no proper access to adequate water and sanitation. The WHO estimates that currently there are 663 million people in the globe that are affected by this pandemic. The consequences of a humanitarian crisis - such as disruption of water and sanitation systems, or the displacement of populations to inadequate and overcrowded camps - can increase the risk of cholera transmission, should the bacteria be 


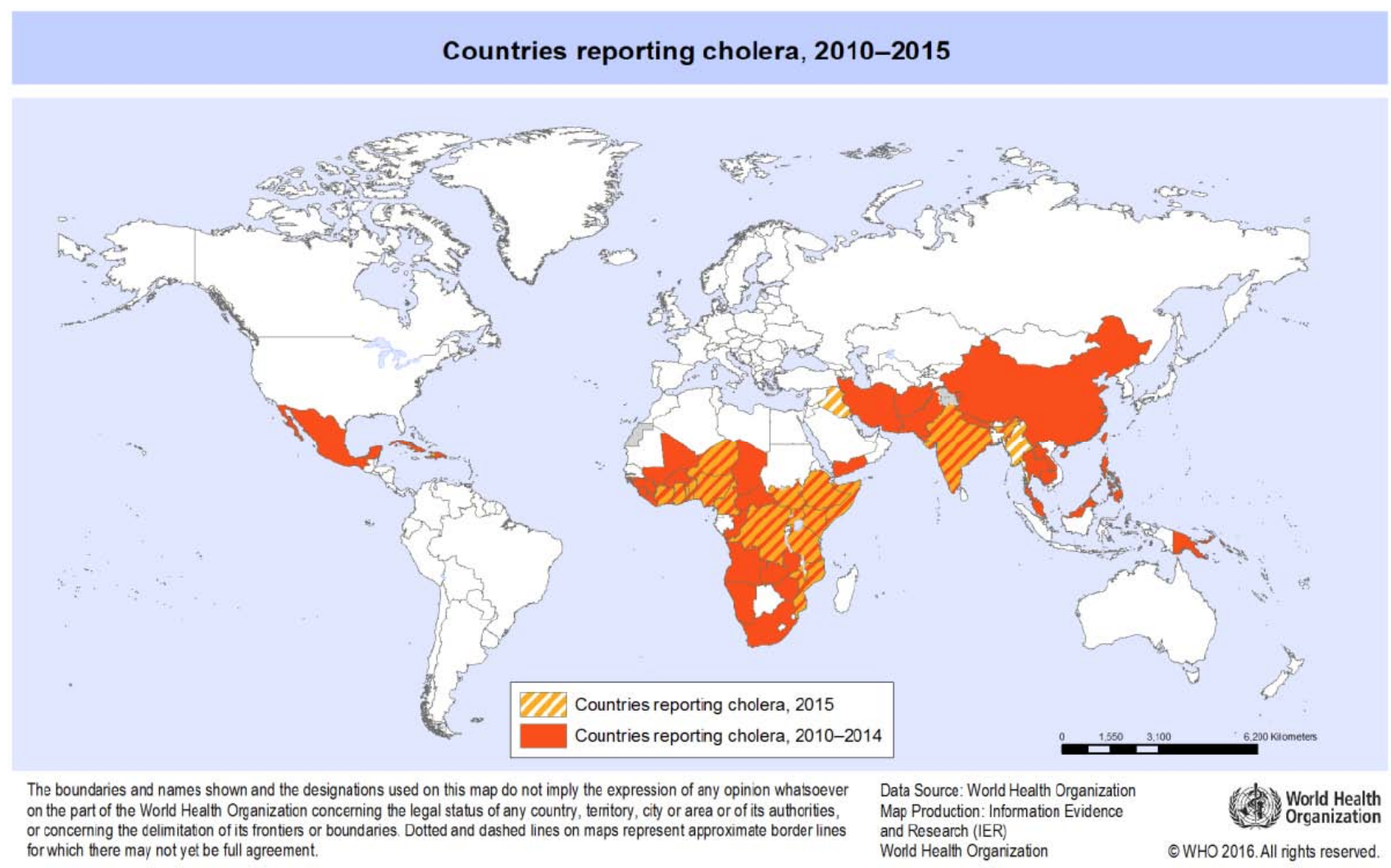

present or introduced. The persistence of the cholera pandemic from 1961 until present times is depicted on the map above for the period 2010-2015.

HIV/Aids is another epidemic that continues to claim human lives. The virus is one of the most devastating infectious diseases to have emerged in recent history. It attacks the human immune system, which makes the person prone to opportunistic illnesses resulting in fatal consequences. Scientists believe that the virus was prevalent since the 1920s in the Democratic Republic of Congo (DRC). The origin of HIV has been a subject of scientific research and debate since the virus was identified in the 1980s. It is now confirmed that the virus was transmitted from primates to humans in the DRC. Currently, there is a wealth of evidence on how, when, and where HIV first began to cause illness in humans (Avert, 2020). According to UNAIDS (2020), there were approximately 38 million people globally living with HIV in 2019 of which 690000 died from AIDS-related illnesses. For the same period, there were 1.7 million new infections. With the discovery of anti-retroviral drugs in the 1990s, it has dramatically improved survival although the life expectancy is limited (Mascolini, 2016). New HIV infections have been reduced by $40 \%$ since the peak in 1998 (Worldometer, 2020). The WHO also advises that a person living with HIV can resume a high quality of life with treatment. It is estimated that some 20.9 million people worldwide were receiving ART as of mid-2017 (Felman, 2018). It will be noted from the map below that the death rate for Africa as a continent is enormous, with the highest concentration in SubSaharan Africa.

In the $21^{\text {st }}$ Century, the swine flu pandemic was caused by a new strain of H1N1 that originated in Mexico in the spring of 2009 before spreading to the rest of the world. In one year, the virus-infected as many as 1.4 billion people across the globe and killed between 151,700 and 575,400 people. Between 2014 and 2016, the Ebola virus claimed 11325 deaths with 28600 infected. The first case to be reported was in Guinea in December 2013. The disease rapidly spread to Liberia and Sierra Leone. The bulk of the cases and deaths occurred in those three countries. A smaller number of cases occurred in Nigeria, Mali, Senegal, the United States, and Europe. There is no cure for Ebola although research is continuing. The Zika virus epidemic originated in South and Central America more recently (2015 to date). The virus is spread through mosquitoes and sexual transmission. Research into the cure for this virus is still ongoing (Jarus, 2020).

By far the greatest pandemic in recent time is the Covid-19 virus which has afflicted 23895181 cases 


\section{Death rate from HIV/AIDS, 2017}

The annual number of deaths from HIV/AIDS per 100,000 people.

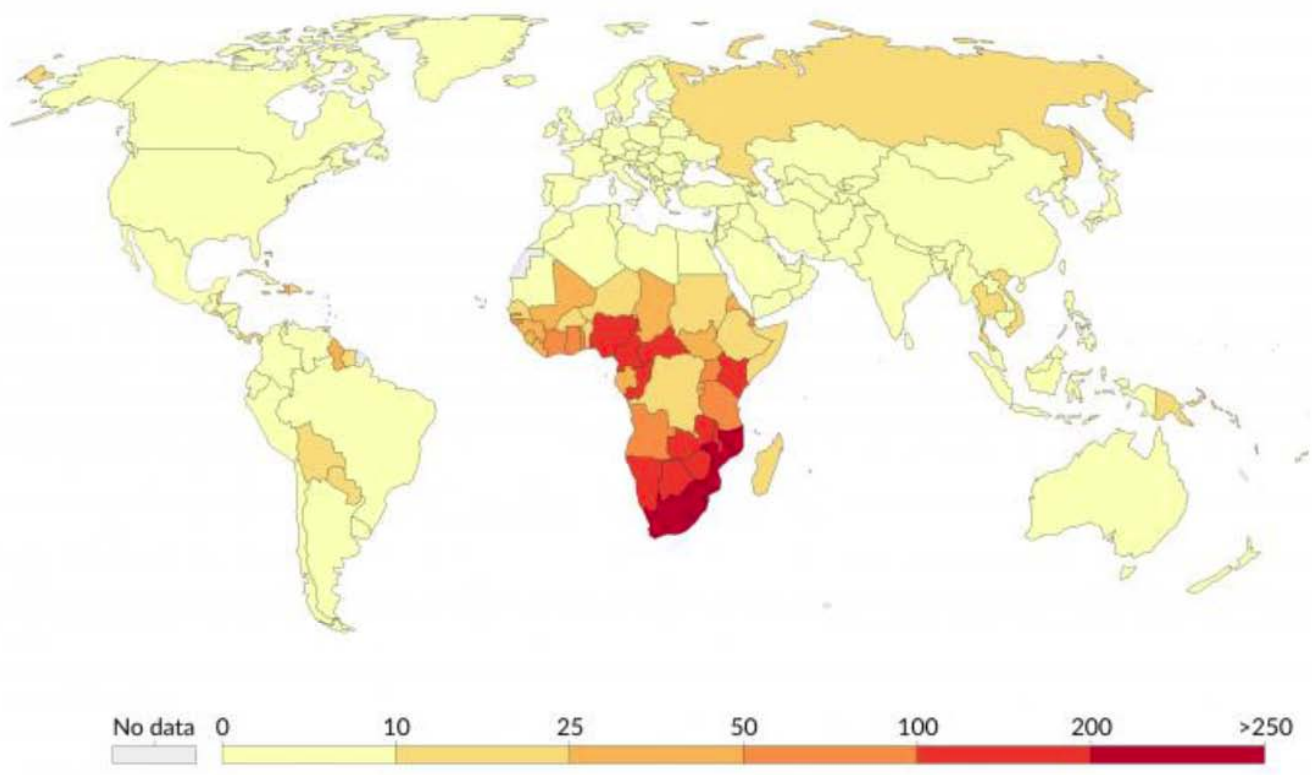

Source: IHME, Global Burden of Disease [GBD)

Note: To allow comparisons between countries and over time this metric is age-standardized.

OurWorldinData.org/hiv-aids • CC BY

and claimed the lives of 820264 globally. It was first identified in January 2020 and the WHO advised nation-states to ensure a total lockdown of all activities to lower the incidence of the virus spreading. Interestingly, most of the identified cases of COVID-19 in Africa have been imported from Europe and the United States, rather than from the original COVID19 epicentre China (Lone and Ahmad, 2020). The lockdown of nation-states was aimed at isolating the population so that the virus does not spread due to physical contact. To date, scientists have not been successful in producing a vaccine that can contain the virus. Nonetheless, great strides have been made in reducing mortality rates. The WHO monitoring of the spread of the virus in the globe is highlighted in the map that follows.

\section{PANDEMICS IN THE AFRICAN CONTINENT}

Africa as a continent has not been immune to some of the pandemics that gripped the globe in pre-historic and modern times. Its response to pandemics was determined in the context of socio-economic and political events in the continent during its history. Precolonial medical history of the African continent is an unexplored field, even the information that is available is scanty, scattered, and mostly descriptive (Patterson, 1974). In this respect, Heaton and Falola (2006) suggest that the study of pandemics in Africa must be within the social or local history of a given space. They observe that some research focuses on an entire African colony, while others focus on smaller local regions within the historical context in which the pandemic has arisen and the effect that the pandemic might or might not have on the political, economic, or religious structures of a specific area. These studies tend to work within a broad temporal framework in a specific region and do not engage in comparisons across space (Heaton and Falola, 2006).

The fourteenth-century may be described as an age of sail, as sea routes were being discovered by Europeans across the Atlantic and the Indian oceans. It is known that the Nordic Vikings were the earliest to transmit goods and animals from North America. These sea trade routes across national and continental boundaries may be dubbed as an era of the earliest stage of globalisation as the plague was not localised and spread rapidly across continents (Sibanda, 2020).

In the African continent, sea and river trade was also an economic activity for the medieval indigenous population. Seafaring from Europe to the north of Africa spread the Black Death pandemic between 1347 to 1351. The plague in North Africa was largely concentrated in cities killing up to fifty percent of the 


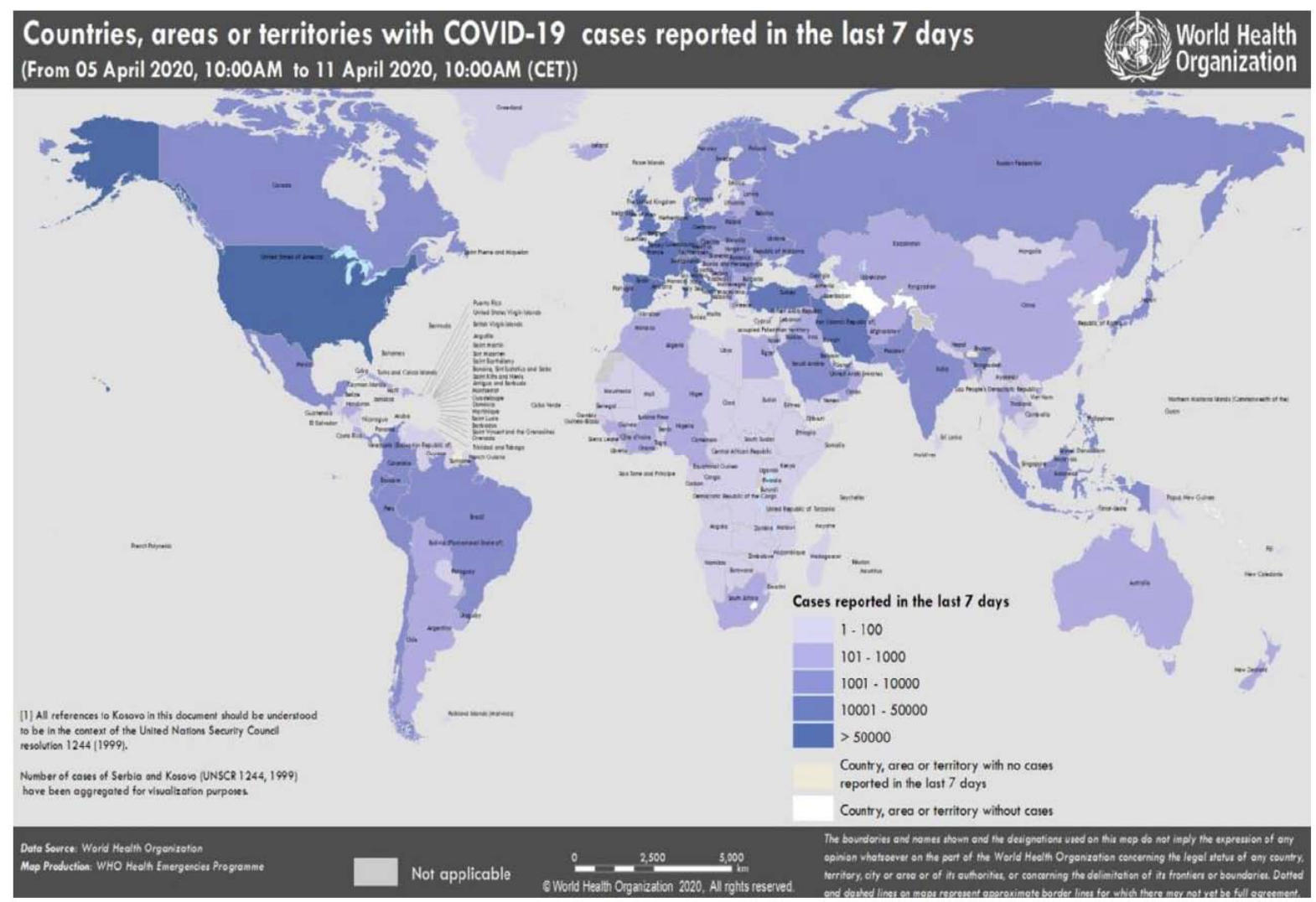

population. There is some contestation as to whether the pandemic extended itself beyond the sub-Saharan region. From the sparse records on the pandemic and gauging from the fact that no "plague pits' resembling those in Europe can be found and neither the $15^{\text {th }}$ and $16^{\text {th }}$ Century white explorers on the continent had anything to say in their records, suggests that this part of Africa was not afflicted. However, recently it is postulated that only ancient DNA could confirm this speculation (Wade, 2019).

Since sea travel became an important transport mode for economic activity, explorers also took the opportunity to venture into the continent resulting in the colonisation of coastal cities and towns in the continent. Slave trade from the African coastland across the North Atlantic was a major economic activity bringing Europeans into contact with native Africans. These voyages carried with them death and diseases resulting in most colonists being afflicted by the outbreak of yellow fever. With resistance from the indigenous, many ships returned disease-ridden and lacked healthy sailors to complete their voyage. By 1793, yellow fever plagued the Atlantic World and Africa (Smith, 2018). In the $21^{\text {st }}$ Century, yellow fever continues to be endemic in tropical areas of Africa and Central and South Africa. In Africa 27 countries were found to be at the highest risk with an estimated 84
000-170 000 severe cases and $29000-60000$ deaths annually (Smith, 2018).

The Spanish flu of 1918 is another pandemic that left widespread devastation in Africa. Troops returning from World War I are known to have spread the virus in the continent. The first wave originated from the Mediterranean coast cities to North Africa, Ethiopia, South Africa followed by a second wave through the seaports of West Africa, Sierra Leone, Ghana, Gambia, and Cameroon. The ports of Mombasa and Djibouti were simultaneously the points of exposure in East Africa. In January and July 1918, a third wave began compounding the devastation (Africa Center for Strategic Studies). The spread of the Spanish flu in the continent is presented on the map below.

During the 19th century, cholera spread across the world, and Africa was equally afflicted by this pandemic. Cholera transmission is closely linked to inadequate access to clean water and sanitation facilities. Typical at-risk areas include peri-urban slums and camps for internally displaced persons or refugees, where minimum requirements of clean water and sanitation are not met. The cholera outbreak ravaged northern and eastern Africa between 1899-1923 (History.Com Editors, 2020). No further outbreaks were reported in Africa until the seventh pandemic that 


\section{AFRICA CENTER
FOR STRATEGIC STUDIES}

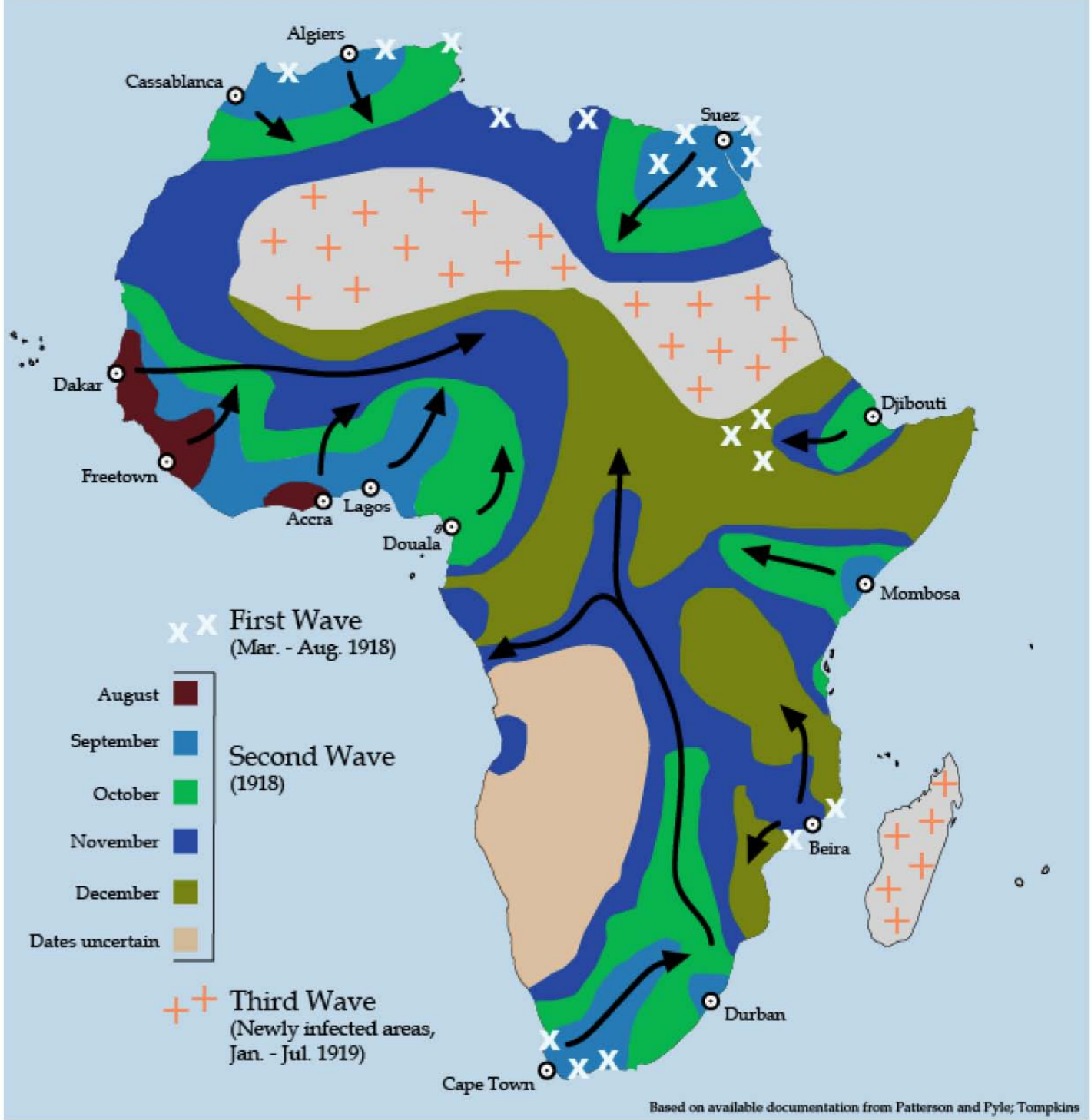

reached the continent in 1970, (Mengel et al. 2014). Within Africa, half of all cases between 1970 and 2011 were notified from only seven countries: Angola, the Democratic Republic of the Congo, Mozambique, Nigeria, Somalia, Tanzania, and South Africa (Mengel et al., 2014). According to the WHO each year, cholera infects 1.3 to 4 million people around the world, killing 21,000 to 143,000 people (WHO) (History.Com Editors, 2020). In 1990, more than 90 percent of all cholera cases reported to WHO were from the African continent (History.Com Editors, 2020).

Africa being the catchment continent for the cholera pandemic is due to structural conditions prevalent within it. During the colonial period, infrastructure such as clean water and sanitation were poorly developed within nation-states for native Africans. In the postcolonial period, this underdevelopment perpetuated itself as its newly found freedom carried with it enormous infrastructure deficits from the past. Political instability, drought conditions, famine, and lack of medical facilities further compounded the cholera pandemic resulting in massive fatalities.

Four decades ago, the Ebola virus originated near the Ebola River in what is now the Democratic Republic of Congo (DRC). Since its origin in 1976, Ebola spread outside of the continent to countries such as the United Kingdom, United States, Italy, Spain, Russia, and the Philippines. In Africa, Cote D'Ivoire, Democratic Republic of Congo, Gabon, Liberia, Mali, Nigeria, Senegal, Sierra Leone, South Africa, Sudan, and 
Uganda were afflicted by this pandemic (Centers for Disease Control and Prevention, 2020).

Although there is some evidence to suggest that Ebola originated from animal species, scientists continue their search for the source of the pandemic. During the earliest outbreaks, the use of contaminated needles and syringes enabled the transmission and amplification of the Ebola virus. During the first outbreak in the DRC, nurses reportedly used five syringes for 300 to 600 patients a day. This close contact with infected blood, reuse of contaminated needles, and improper nursing techniques were the source for much of the human-to-human transmission during early Ebola outbreaks. As early as 2018 there were 3470 reported cases of which 2287 were either dead or in the stage of fatality (Centers for Disease Control and Prevention, 2020).

In the early 1980s, the continent was gripped by yet another life-threatening pandemic that affects the human immune system. It came to be known as the human immunodeficiency virus (HIV) and acquired immunodeficiency syndrome (aids) which is the most advanced stage of the disease. This deficiency places one at risk of acquiring serious infections and certain forms of cancer. It is the final stage of infection with HIV. The WHO Regional Office for Africa (2020) estimates that at present a quarter $(25.7 \%)$ of the continent's population is HIV positive with 470000 Aids-related deaths in 2018. For the same period, the virus-infected 1.1 million people. The enormity of the pandemic in the continent is the observation that three million people died from AIDS in 2001 (Dixon, et al. 2002).

In the present time, Covid-19 has plagued the globe. It is a virus discovered in early January in China, which causes COVID-19. It appears to be transmitted through droplets spread by coughing or sneezing. On 14 February 2020, Africa confirmed its first COVID-19 case in Egypt. Since then, more than 1 million cases have been reported and every country on the continent is affected. The continent has the second-lowest number of coronavirus-infected people dying from Covid-19 of six world's regions, according to data from John Hopkins University (Mo Ibrahim Foundation, 2020). The number of confirmed cases as of 29 July 2020 was 874,036 , active cases 330,981 , recoveries 524,557, and several deaths 18, 498 (Shaban, 2020). Africa's low levels of infection may be attributed to Africa being more prepared in managing the public health crisis because of the Ebola and the HIV pandemics. With a continent with the highest number of people, living with HIV there have been fears of a catastrophic episode should a breakout of the Covid-19 occur simultaneously. Africa is not a very healthy continent. According to the Infectious Disease Vulnerability Index (IDVI) 2016, out of 25 countries that are most vulnerable to infectious diseases are in the African continent. There are 26 million people infected with HIV, 2.5 million with tuberculosis, 71 million with hepatitis B or C, and 213 million with malaria in the African region. Moreover, the double burden of noncommunicable diseases (NCDs) such as cardiovascular diseases, cancers, chronic respiratory diseases, and diabetes are also immensely significant in Africa. All of these conditions compromise the body's immunity. Therefore, it could be reasonably hypothesized that the majority of the African population, due to their immunocompromised health will be at high risk to infectious diseases (Lone and Ahmad, 2020).

\section{THE IMPACT OF PANDEMICS IN THE CONTINENT}

Pandemics by their very nature are unpredictable as the extent to which they will affect a nation and the globe cannot be stated with certainty. Africa is home to approximately $1,3 \mathrm{bn}$ people, which makes up $16.72 \%$ of the total world population of which $43.8 \%$ are urban. It is a youthful continent with the median age being 19.7 years (Worldometer, 2020a). In the historiography of Africa, it was the centre for large-scale exploitation of economic resources by colonialists, which in part explains its underdevelopment. The remnants of colonial exploitation were to such an extent that sovereign states after democracy were unable to recuperate from this historical milestone into the $21^{\text {st }}$ Century. The carryover since sixty years of independence is immense with $40 \%$ of people in Africa living below US\$1.90 a day. Those living in subSaharan Africa are more than twice as likely to live in poverty and make up $60 \%$ of the global population that is in a state of poverty (Institute for Security Studies, 2020). More than half of all African urbanites live in slums, constituting well over 200 million people (Burrows and Engelke, 2020).

Climatic changes in Africa have also largely affected Africa's development. Extreme weather conditions have been a source of much devastation by floods and severe droughts that affects agricultural output and growth. Famine, food insecurity, diseases, and a lack of basic infrastructure become the cornerstone of extreme poverty. Political instability after independence 
has further compounded the plight of Africans in the continent. Ethnic violence, coups, terrorism, armed conflict, insurgency, and social unrest has affected the well-being of nation-states (African Development Bank, 2020). Given the perilous status of African states, in times of major pandemics, it places many demands on its ability to cope with, thus straining the provision of basic services, which otherwise would be of national priority. Hence, the continent is dealt a double blow in its ability to cope with pandemics and at the same time provide, and sustain service delivery.

At a micro level, widespread fear and anxiety take their toll on the mental health status of those living in pandemic-afflicted countries. Uncertainty about the future, fear of coming into contact with the virus and conformity to national measures to curb the virus spreading, changes in social, political, and economic activities all impact the mental health state of pandemic stricken countries. Africa's mental health services are poorly developed and policies are not consistent in the region amongst nation-states to be effective in dealing with the distress that emanates during and after pandemics. The continent has 1.4 mental health workers per 100000 people, compared to the global average of 9.0 per 100000 . Additionally, there is a lack of facilities to manage severe mental health cases (Sankoh, 2018). Unclear communication and at times conflicting information further causes confusion about the nature and precautions that needed to be taken during the pandemic. False rumours and speculation also exacerbate panic, which raises anxiety levels. Untested medical healing practices by traditional doctors and fear of taking western forms of medicine are part of the socio-cultural constraints prevalent during the pandemic.

African countries face critical shortages of hospital beds, personnel, and equipment to deal with serious cases afflicted by pandemics. Fiscal constraints and lack of local expertise result in procuring medical resources from developed countries at a cost, so are the cost of pharmaceutical products and ongoing medical treatment. Makeshift medical facilities and conversion of public amenities to deal with serious cases further weigh heavily on the health budget. Considering that $56 \%$ of the continent's population live under rural condition as compared to urban (44\%) (Worldometer, 2020b) where most of the medical resources are concentrated, carrying the burden of poor access to health care facilities and services becomes a challenge for rural communities. Poor health and sanitation further compound the spread of the pandemic.

Children, youth, the elderly, the disabled, and the chronically ill are most vulnerable during times of pandemics. Pandemics leave behind a trail of human casualties comprising orphans, widows, widowers, child and single-parent headed households. The social shocks of pandemics can be felt at the very foundation of societal life. The educational sector is disrupted by periodic shutdowns, places of worship are abandoned, family and social gatherings are restricted, recreational activities are curtailed and curfews implemented. All of this weighs heavily on social stability and functioning.

Pandemics impact seriously the economy of countries. Travel (sea, land, and air) restriction bans virtually isolate the global flow of goods and capital both within and outside the borders of nation-states. The economic costs are phenomenal resulting in the diversion of resources to fight the pandemic at the cost of existing essential services. With nation-states being already cash strapped, borrowing becomes a necessity, further contributing to the debt burden that African states find themselves. As companies close or slow down production, unemployment rates surge so are employees put on half-pay. Youth account for $60 \%$ of all of Africa's jobless and pandemics exacerbate this vulnerability (Ighobor, 2017). Local production of goods is curtailed and there is a dependency on imported products resulting in a decline in export earnings in strategic sectors of the economy. Travel restrictions affect the tourism industry and the foreign currency it generates. Africa is known for its lucrative tourism industry and many countries are dependent on revenues derived from this sector. Restaurants and food outlets also become constrained due to pandemics.

Given the extent of underdevelopment in Africa, in times of pandemics, it turns to donor agencies to support its fragile economy. This economic support from developed countries is contingent on how they will reassess their interest in engaging Africa during and after pandemics. There is a cost-benefit principle underlying relationships with developed countries during times of pandemics. Developed countries that provide aid will expect rewards for their engagement from afflicted states (Dixon et al., 2002). Africa as a continent has broken away from the vicious stronghold that colonial rule had on all aspects of life. Postliberation, Africa has to compete in a globalised world 
and given its poor state of development, its ability to be competitive with the rest of the world has not been promising. At a political level in $21^{\text {st }}$ Century Africa, the standoff between America and China on their foreign policy in the continent will determine the nature and extent to which African nation-states can interface with these foreign powers to procure aid during and after a pandemic (Burrows and Engelke, 2020).

\section{REGIONAL AND CONTINENTAL RESPONSE TO PANDEMICS}

The response to pandemics is just not a medical one but requires a consolidated response at a regional and continental level. It requires a reaffirmation of commitment to warrant the harmonisation and coordination of national policies and the promotion of integration programmes, projects, and activities in the different regions so that mechanisms are in place to both prevent and lower the incidence of the pandemic spreading. The problem of dealing with a public health crisis is further exacerbated by low levels of spending on the continent's health care system (5.6 percent of GDP) as compared to the world average of 9.9 percent (United Nations Economic Commission for Africa, nd).

Among the issues that exacerbate the challenges to effectively dealing with public health, crisis is low levels of health spending on the continent (5.6 percent of GDP) compared to a world average of 9.9 percent. Limited hospital bed capacity (1.8 beds per 1,000 people) low access to household handwashing facilities (34 percent for those with soap and water); and a heavy dependence on imports for pharmaceutical products are part of the challenges. For 2018, an amount of USD $3.6 \mathrm{bn}$ net imports of pharmaceutical products was procured (United Nations Economic Commission for Africa, nd).

A regional response to pandemics can be mitigated by timely monitoring, predicting, assessing preparedness, and responding during early warning signs of pandemics. For instance, infectious diseases such as Ebola pose an ever-increasing threat to health, security, and development in Africa. According to the World Bank between 2014-2016, the Ebola outbreak in West Africa resulted in over 11,000 deaths in Guinea, Sierra Leone, and Liberia and the estimated economic impact of the outbreak was USD $2.8 \mathrm{bn}$ on the three countries. It is estimated that had the response to the Ebola pandemic had been two months earlier it could have averted the fatalities by up to $80 \%$ in Sierra Leone and Liberia (Medinilla et al., 2020).
The Covid-19 pandemic in certain ways has alerted the globe towards a continental and regional response to pandemics. Pandemics do not respect borders and the failure of a country to limit the infection rates results in its neighbors being afflicted. One of the ways to contain the spread of the pandemic is through regional responses in the continent. In Africa, there is familiarity with the management of outbreaks of infectious diseases such as Ebola, TB, and HIVIAids and how to curb this from spreading through regional coordination. The World Bank has been active in facilitating regional response through proactive steps in detecting and responding to outbreaks (Wetzel, 2020)

The African Union (AU) plays an important role in bringing regions together so that the response is a collective effort in the continent. AU is known to have played an effective role in communicating about and shaping African responses to pandemics, with technical resources provided through the Africa Centre for Disease Control (Medinilla et al., 2020). The establishment of the Africa Centre for Disease Control (CDC) is a huge step for the continent in providing a continent-wide platform to coordinate infectious disease management (United Nations Economic Commission for Africa). The CDC provides coordination of local and international partners' activities, provides technical guidance related to laboratory testing, contact tracing, infection control, border health screening, data management, risk communication, and health education, vaccination, and logistics (Centre for Disease Control, 2020).

During the Covid-19 pandemic, the Economic Commission for Africa (ECA) established a forum for Regional Economic Communities (RECs) on 13 May 2020. It explored the potential for greater healthcare integration in the continent with representatives from Arab Maghreb Union (AMU), the Community of SahelSaharan States (CEN-SAD), Common Market for Eastern and Southern Africa (COMESA), Harmonisation of Sectoral Policies (COMESA), East African Community (EAC), Economic Community of Central African States (ECCAS), Economic Community of West African States (ECOWAS), Intergovernmental Authority on Development (IGAD) and Southern African Development Community (SADC) (United Nations Economic Commission for Africa). The participation of regional blocks representing all parts of the continent provided a commitment to expand the scope of healthcare cooperation and integration in the continent. However, this is contingent on the local contexts that RECs find themselves in terms of their institutional 
histories, structural features, and political economy dynamics of countries in the region (Medinilla et al., 2020).

The United Nations Commission for Africa envisages enhancing information sharing on continental and regional levels to better formulate effective data-driven policies to manage pandemics. Sharing expertise through the training of frontline workers and coordination of border security policies and measures to limit disease transmission between countries and enable goods and services to continue flowing, particularly for economies dependent on imports for food and fuels, as well as landlocked countries are some of the priority areas (United Nations Economic Commission for Africa, 2020). It also envisages pooled procurement and incentivizing locally manufactured pharmaceutical products to capitalise on a larger size of the African market so that dependency on imports is reduced. Further, this will promote local economic development and reduce the exorbitant costs involved in procuring from multinational pharmaceutical companies.

\section{CONCLUSION}

This article provides a broad insight into how throughout history, disease outbreaks have ravaged humanity. It sometimes changes the course of history and, at times, creates panic that the end of time has neared. Pandemics know no borders and Africa has not been immune to it. The cost of the devastation in the African continent is multi-fold and complex given several other endemic diseases afflicting the continent. The historiography of pandemics suggests that although early findings allude to its origin in European countries during the time of early trade, colonisation, and wars, Africa to a significant extent contributed to the list of pandemics that plagues the continent and the globe. Pandemics in the continent are more severe due to a large part of it being underdeveloped. Poverty, food scarcity, anemia, malaria, HIVIAIDs, tuberculosis, and poor basic services add to the burden of pandemics. The health sector does not have the basic medical equipment and human resources to extend itself effectively in times of pandemics. The cost of pharmaceutical products is beyond the reach of many African nations. These challenges extend to most of Africa and it is dependent on donor funding and loans to sustain its health sector. Notwithstanding, Africa has made great strides in equipping itself to deal with lethal diseases. This is through engagement with nationstates to form partnerships, alliances, and cooperation in each region and the continent as a whole. Facilitated by the AU, World Bank, Africa Centre for Disease Control under the aegis of the UN and other stakeholders has advanced its ability to cope with pandemics. With the discovery of vaccinations, certain infectious diseases that have been considered previously persistent and lethal have now been eliminated or drastically reduced. In the management of the Covid-19 pandemic, Africa contrary to the prediction by experts that it would be challenging to control and consequences dismal, has to a vast extent dealt with the impending catastrophe, with resilience.

\section{REFERENCES}

Africa Center for Strategic Studies, 2020 Lessons from the 19181919 Spanish Flu Pandemic in Africa

African Development Bank 2020. African Economic Outlook. https://www.afdb.org/en/documents/african-economicoutlook-2020

Avert 2020 Origin of HIV and Aids. Global Information and Education on HIV/Aids. $15^{\text {th }}$ August. https://www.avert.org/ professionals/history-hiv-aids/origin

Barberis, I., Myles, P., Ault, S.K., Bragazzi, N.L. and Martini, M. 2016. History and Evolution of Influenza Control through Vaccination: From the First Monovalent Vaccine to Universal Vaccines Journal of Preventive Medicine and Hygiene. 2016. 57(3): E115-E120. https://www.ncbi.nlm.nih.gov/pmc/ articles/PMC5139605/

Beegle, K, Christiaensen, L., Andrew L., Dabalen., A and Gaddis, I. 2016. Poverty in a Rising Africa. Africa Poverty Report. World Bank. Washington DC. https://doi.org/10.1596/978-1-4648-0723-7

Benedictow Ole 2005. the Black Death. The Greatest Catastrophe Ever. History Today Volume 55 Issue 3 https://www.historytoday.com/archive/black-death-greatestcatastrophe-ever

Burrows, M.J and Engelke, P. 2020. What World Post-COVID-19? Three Scenarios. The Atlantic Council of the United States. Washington DC. https://www.atlanticcouncil.org/wp-content/ uploads/2020/07/What-World-Post-COVID-19.pdf

Centers for Disease Control and Prevention, 2020. 40 Years of Ebola Virus Disease Around the World https://www.cdc.gov/vhf/ ebola/history/chronology.html

Coulibaly, B.S and Madden, P. 2020 Strategies for Coping with the Health and Economic Effects of the COVID-19 Pandemic in Africa. Africa in Focus. Brookings. https://www.brookings. edu/blog/africa-in-focus/2020/03/18/strategies-for-copingwith-the-health-and-economic-effects-of-the-covid-19pandemic-in-africa/

Dixon, S., McDonald, S and Roberts, J. 2002. The Impact of HIV and AIDS on Africa's Economic Development. British Medical Journal 324(7331): 232-234. https://doi.org/10.1136/bmj.324.7331.232

Felman, A. 2018 Explaining HIV and AIDS. Medical News Today November 29. https://www.medicalnewstoday.com/ articles/17131

Heaton, M. and Falola, T. 2006. Global Explanations versus Local Interpretations: The Historiography of Influenza Pandemic of 1918 in Africa. History in Africa 33: 205-230 Cambridge University Press Stable. https://doi.org/10.1353/hia.2006.0014

History.Com Editors, 2020 Cholera https://www.history.com/topics/ inventions/history-of-cholera 
Ighobor, K. 2017. Africa's Jobless Youth Cast a Shadow over Economic Growth. Africa Renewal. Special Edition on Youth. https://www.un.org/africarenewal/magazine/special-editionyouth-2017/africas-jobless-youth-cast-shadow-overeconomic-growth

Institute for Security Studies, 2020. What is the Future of Africa? https://issafrica.org/iss-today/what-is-the-future-of-poverty-inafrica

Jarus, O. 2020, 20 of the Worst Epidemics and Pandemics in History

Lone, S. A and Ahmad, A. 2020. COVID-19 Pandemic - an African Perspective. Emerging Microbes and Infections. 9:(1) 13001308. https://doi.org/10.1080/22221751.2020.1775132

Mascolini, M. 2016 Narrowing the Gap in Life Expectancy for HIV+ Compared with HIV- Individuals...Life Expectancy Gap between HIV+ and HIV- Narrows But Persists. Conference on Retroviruses and Opportunistic Infections (CROI), February 22-25, 2016, Boston. WEBCAST Link : http://www.croiwebcasts.org/console/player/29469?mediaTy pe=audio\&

Medinilla, A., Byiers, and Apiko, P. 2020. African Regional Response to Covid-19. European Centre for Development Policy Management (ECDPM). Discussion Paper No. 272. Netherlands.

Mengel, M.A., Delrieu, I., Heyerdahl, L and Gessne, B.D. 2014. Cholera Outbreaks in Africa Current Topics in Microbiology and Immunology.

https://doi.org/10.1007/82_2014_369

Mo Ibrahim Foundation, 2020. Africa: Covid-19 - Continent's Low Death Toll Explained https://allafrica.com/stories/ 202008160034.html

Ott, M., Shaw, S.F, Danila, R.N. and Lynfield, R. 2007. Lessons Learned from the 1918-1919 Influenza Pandemic in Minneapolis and St. Paul, Minnesota, Public Health Report. 122(6): 803-810. https://doi.org/10.1177/003335490712200612

Patterson, K.D 1974. Disease and Medicine in African History: A Bibliographical Essay. History in Africa. 1:141-148. https://doi.org/10.2307/3171766

Sankoh, O., Sevalie, S. and Weston M 2018. Mental Health in Africa. The Lancet. https://www.thelancet.com/journals/langlo/article/ PIIS2214-109X(18)30303- 6/fulltext\#: :text=Partly\%20as \%20a\%20consequence $\% 2 C \%$ 20the, is $\% 2014 \% 20$ per $\% 2010$

Shaban, A.R. 2020 Africa Covid-19 Stats. Africa News. https://www.africanews.com/2020/07/29/coronavirus-inafrica-breakdown-of-infected-virus-free-countries

Sibanda, B. 2020 Africa: Tracing the History of Pandemics. The Standard. All Africa. https://allafrica.com/stories/ 202006150640.html

Smil V n/d A Complete History of Pandemics https://thereader.mitpress.mit.edu/a-complete-history-ofpandemics/

Smith, B.G. 2018 The First Yellow Fever Pandemic: Slavery and its Consequences. The New York Academy of Medicine. https://nyamcenterforhistory.org/2018/10/15/yellow-feverpandemic/

UNAIDS 2020 Global HIV and AIDS Statistics - 2020 Fact Sheet https://www.unaids.org/en/resources/fact-sheet

UNAIDS, 2020. Seizing the Moment - Tackling Entrenched Inequalities to End Epidemics. Joint United Nations Programme on HIV/Aids. Geneva.

United Nations Economic Commission for Africa, n/d. Dealing with Health Pandemics in Africa through Regional Cooperation: The case of COVID-19. https://www.uneca.org/oria/pages/ dealing-health-pandemics-africa-through-regionalcooperation-case-covid-19

Wade, L. 2019 The Black Death may have transformed medieval societies in sub-Saharan Africa. https://doi.org/10.1126/science.aax2478

Wetzel, D. 2020 Pandemics know no Borders: In Africa, Regional Collaboration is Key to Fighting COVID-19. World Bank. https://blogs.worldbank.org/africacan/pandemics-know-noborders-africa-regional-collaboration-key-fighting-covid-19

World Bank, 2020 World Bank in Africa https://www.worldbank.org/ en/region/afr/overview

Worldometer, 2020a. Africa Population. https://www.worldometers. info/world-population/africa-population/

Worldometer, 2020b. Africa Demographics https://www.worldometers.info/demographics/demographicsof-africa/\#life-exp

WHO Regional Office for Africa, 2020. https://www.afro.who.int/ health-topics/hivaids

\section{https://doi.org/10.6000/1929-4409.2021.10.184}

(C) 2021 Sultan Khan; Licensee Lifescience Global.

This is an open access article licensed under the terms of the Creative Commons Attribution License (http://creativecommons.org/licenses/by/4.0/) which permits unrestricted use, distribution and reproduction in any medium, provided the work is properly cited. 